\title{
UC-industry-agency partnerships influence and help implement dairy water quality policy
}

\author{
More than 94\% of dairy producers were in compliance with new regulations to protect water \\ quality after a carefully staged, collaborative plan to support the transition to new practices.
}

by Deanne M. Meyer, Betsy M. Karle, Jennifer M. Heguy, David J. Lewis, Jeffery W. Stackhouse and D. Denise Mullinax

\section{Abstract}

\begin{abstract}
For 50 years, UC Agriculture and Natural Resources (UC ANR) has contributed to dairy water quality policy in California and helped, with partner organizations, to implement it in the dairy industry. When conditional waivers for waste discharge requirements expired in 2003, UC ANR shared research and best professional practices as regional water quality control boards developed new orders. UC ANR academics then worked with water quality control boards' staff and dairy industry representatives to develop feasible, staged implementation plans. Collaboratively, more than 50 hours of workshop curriculum were developed and disseminated, helping dairy producers to accept scientifically sound management practices that are more protective of groundwater. Research by UC ANR to better understand system dynamics, nitrogen management and practices to minimize the impact of manure application on groundwater quality continues, as does a program in environmental stewardship.
\end{abstract}

$\mathrm{P}$ assage of the Porter-Cologne Act, California's water quality regulation, in 1969 and the addition of point source regulations to the federal Clean Water Act in 1972 created a path to reduce the impacts of livestock operations on water quality. Water is an important resource for Californians. In the dairy industry, water is used directly for animal consumption, milk harvesting hygiene and sanitation, milk cooling, animal cooling and also for on-site forage production. Two important ways in which dairies conserve water are the use of manure-based fertilizers for on-site forage production, and the use of feeds that are byproducts of human food production (almond hulls, distillers grains, cottonseed, etc.). The human edible outputs from the industry are milk and meat. The industry also produces solid manure and process wastewater (very dilute manure), which require management to minimize the potential impact to surface water and groundwater sources.

Online: https://doi.org/10.3733/ca.2018a0042

\section{(4)}

Manure management practices based on UC ANR research and delivered through educational workshops have helped hundreds of California dairy farmers comply with regulations designed to protect water quality.
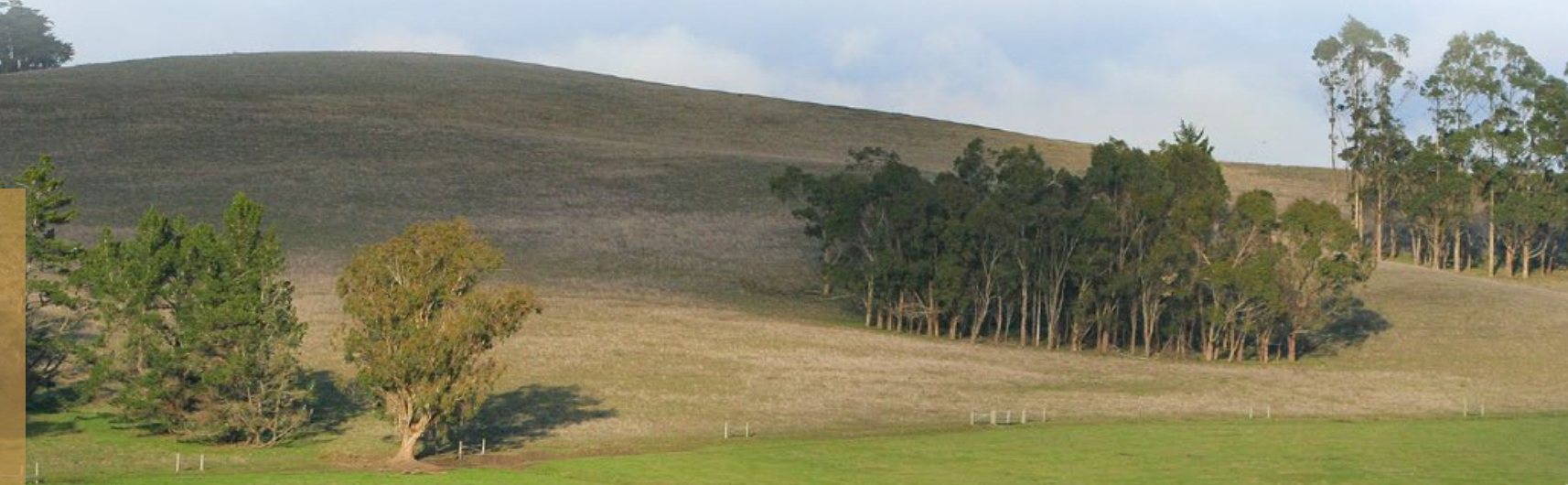
In the 1970s, the State Water Resources Control Board (SWRCB) worked to incorporate the 1972 Clean Water Act requirements for concentrated animal feeding operations into the Porter-Cologne Act. The SWRCB requested information from UC Agriculture and Natural Resources (UC ANR) on manure generation on dairies and best practices for manure management. Since that time, UC ANR has worked collaboratively with the SWRCB, regional water quality control boards, industry organizations and dairy owners, providing research and educational programs to generate science-based policy and guide its implementation.

\section{Contributing science to regulatory framework}

UC ANR's earliest work with the SWRCB, on identifying better practices for manure management, was used during the decade leading up to development of statewide regulations adopted in 1984 (previously Chapter 15: \$2560-2565, now located in Chapter 7, subchapter 2 , Article $1 \$ 22560-22565$ ) (California Code of Regulations). Technical information was provided on soil qualities important for dairy pond structure (\$22562) and the importance of having manure storage structures contain at least $10 \%$ clay and not more than $10 \%$ gravel or other impermeable material. Also, technical information was provided on manure nutrient use in crop production systems $(\$ 22563)$ : “The application of manure to crop lands shall be at rates reasonable for the crop, soil, climate, special local situations, management system, and type of manure."

In response to the statewide regulations adopted in 1984, regional water quality control boards were tasked with developing Conditional Waiver of Waste Discharge Requirements (CWWDR) or Waste Discharge Requirements (WDR). WDR were developed with or without the federal Clean Water Act National Pollutant Discharge Elimination System permits, depending on local needs. Beginning in the late 1970s, UC ANR advisors convened local groups of dairy owners and operators to discuss the implications of the new regulations, identify alternative manure management practices and engage in local monitoring to benchmark and document progress.

The state's regulatory process for issuing water quality permits changed in 2003 with the passage of Senate Bill 293, which mandated a sunset to the existing CWWDR. In practice, this required that each regional water quality control board reissue its conditional waivers on a 5 -year cycle or issue WDR. Both processes required intensive public input.

As change agents, UC ANR (UC Cooperative Extension) advisors and specialists were actively engaged with stakeholders to provide science-based information to staff at regional water quality control boards as they developed and adopted WDR for dairies.
Technical questions arose prior to and during the policy development process. Research findings and best professional understandings provided by UC ANR academics informed policymakers during the 2-year process of drafting the Central Valley (RB5) Dairy General Order (CVRWQCB 2007; CVRWQCB 2013). UC ANR also provided scientific input during development of dairy regulatory processes by the North Coast (RB1) (NCRWQCB 2012) and San Francisco Bay (RB2) (SFBRWQCB 2015) regional water quality control boards.

\section{Building partnerships}

The California Dairy Quality Assurance Program (CDQAP) Environmental Stewardship module was founded in 1997, a partnership between dairy industry groups; federal, state and regional government agencies; dairy science researchers and UC ANR. Its first project was to collaboratively establish a mechanism to certify dairies in environmental stewardship. It was proactive in addressing environmental concerns, setting up the voluntary certification project before the adoption of water quality regulations that targeted nitrogen management (CVRWQCB 2007; CVRWQCB 2013; NCRWQCB 2012; SFBRWQCB 2015). In addition to joint work between UC ANR and CDQAP, active participation from U.S. Department of Agriculture Natural Resources Conservation Service (USDA NRCS), resource conservation districts and regional boards' staff members remains important to the success of the programs.

The project received a grant in 1999 from the U.S. Environmental Protection Agency in support of its goal to encourage dairy operators to adopt more environmentally sustainable management practices to manage manure and protect water quality. Practices needing attention included managing production areas prior to winter rains to maximize collection of rain runoff from solid manure containing areas, conditioning corrals to minimize erosion during rain events, evaluating liquid manure storage capacity, using water more efficiently and carefully timing application of nutrients to soil during growth of winter and summer crops to more closely match crop nitrogen needs. Enhanced management helps to prevent erosion and retain nitrogen nearer to crop root zone for use.

The requirements for becoming certified in environmental stewardship include attending a 6-hour UC ANR dairy environmental stewardship course (dairy water quality and dairy manure management). Also, the dairy operator or owner needs to document compliance with local, state and federal regulations pertaining to environmental stewardship and successfully complete an on-farm evaluation by an independent third party with no previous ties to the facility or affiliation with facility management. UC ANR academics were deeply involved in developing the on-farm evaluation
UC ANR has worked collaboratively with the SWRCB, regional water quality control boards, industry organizations and dairy

owners, providing research and educational programs to generate sciencebased policy and guide its implementation. 
tool to delineate compliance with water quality regulations and to evaluate probability of compliance based on infrastructure available for manure management and management capabilities. The evaluation checklist was finalized through a series of ten 3- to 5-hour meetings by staff from the SWRCB, regional water quality control boards, US EPA, California Department of Food and Agriculture, dairy industry representatives and UC ANR.

\section{Central Valley Dairy GWDR}

In 2000, the Central Valley Regional Water Quality Control Board (CVRWQCB) asked UC ANR to address technical questions posed by its staff on manure nitrogen distribution, atmospheric nitrogen losses, nitrogen application rates, phosphorus and potassium concentrations in manure, salts in dairy manure and the effects of applying manure to land (Chang et al. 2006). A committee of UC ANR experts on these subjects was convened. The findings of the committee's report, specifically that nitrogen application rates of 1.4 to 1.65 times the nitrogen removal rates in harvested crops are protective of groundwater quality, served as the foundation of the GWDR (for existing milk cow dairies [CVRWQCB 2007, 2013]) nitrogen application restriction developed in 2007.

Many of the experts on the committee also To help dairy operators estimate manure storage pond capacity needs, workshop leaders set up office hours where they provided one-on-one assistance with site-specific calculations. management involved with dairy operations. Together, the group worked with stakeholders and CVRWQCB staff to identify logical, methodical ways that producers could effectively implement changes to their operations to be more protective of groundwater quality and meet compliance needs.

In 2003, after the mandatory sunset of conditional waivers, the CVRWQCB began to develop dairy-specific GWDR for existing milk cow dairies through a series of stakeholder meetings. Included were concerned citizen groups, USDA NRCS state experts, UC ANR academics, dairy industry representatives and county regulatory agency staff.

The primary focus of the dairy GWDR was better management of all forms of nitrogen to minimize nitrate leaching through soil. Existing knowledge (in industry, UC ANR and USDA NRCS), findings from then-current research (from UC ANR) and identification of standard practices (from USDA NRCS, industry, UC ANR) were integrated to establish a staged implementation process for the dairy GWDR (CVRWQCB 2007).

The trust developed during the initial years of the environmental stewardship program was invaluable. Stakeholders who knew one another provided scientific input during numerous dairy stakeholder working group meetings with dairy program staff at CVRWQCB. UC ANR academics provided written and oral public comments and contributed research publications and findings during working group meetings. Once the dairy-specific GWDR program was finalized, the next hurdle was delivering it to the dairy industry in a way that would result in positive management change by dairy owners and operators. They were required to change from doing what they had been doing for decades to, for example, maintaining detailed water quality records and submitting annual reports. UC ANR collaborated with its partners in CDQAP to develop workshops for dairy operators and their consultants. UC ANR led the workshop curriculum development and dissemination processes.

UC ANR contributed research on the infiltration of nitrate-nitrogen into groundwater below fields farmed for forage crops to be fed to dairy cows (Harter et al. 2002; Harter, Davis et al. 2001; Harter, Mathews et al. 2001; Mathews et al. 2001). It was key to dairy producers making nitrogen management a priority.

The final 6-stage implementation plan for complying with the dairy-specific GWDR was a methodical approach to managing nitrogen applications. It consisted of (1) identifying current facility infrastructure and nitrogen application and water management capabilities; (2) evaluating sufficiency of existing infrastructure for more detailed needs of a future system; (3) determining a feasible implementation plan to get from current structures to future needs in a limited time frame (as defined in the GWDR); (4) completing retrofits as needed; (5) evaluating effectiveness and (6) making additional improvements. 
In fall 2005, UC ANR and CDQAP delivered a workshop in the Central Valley to dairy operators. The primary focus of this workshop was introducing pending changes in the regulatory process and providing an opportunity for each dairy facility owner to identify the facility is in operation and exists (a California Environmental Quality Act process).

In 2006, UC ANR published California Dairies: Protecting Water Quality, which summarized practical approaches and technologies to protect water quality and aid dairy producers in positioning their facilities to comply with the impending regulations (Ristow et al. 2006). For dairies with irrigated cropland, recommended management practices included assessing farm nitrogen balance and improving manure recordkeeping systems, upgrading liquid manure distribution systems to quantify application rates, exporting manure nitrogen off-site, increasing storage capacity by reducing the volume of water generated in the milking parlor, applying nitrogen (manure and nonmanure sources) at agronomic rates and modifying irrigation systems to improve water use efficiency and distribution uniformity.

UC ANR advisors and specialists worked with their CDQAP partners to create educational programming for Central Valley dairy operators under the jurisdiction of the regional board. Starting in 2007, the 3-hour workshops and outreach meetings held throughout the Central Valley, altogether more than 33 hours of curriculum, presented technical and agricultural science knowledge to help dairy operators and consultants start to implement the GWDR and information on its detailed regulations. When the dairy GWDR was adopted, the CDQAP environmental stewardship program was 7 years strong. Though farmers knew that change was coming, they were unprepared for the GWDR's 125 pages of regulatory text, and few understood the nuances of compliance.

The workshops were held at 6-month intervals beginning in fall 2007, after the GWDR was adopted, for the first 2 years and then annually. Grants from the California Dairy Research Foundation offset costs for workshop materials. Attendees were provided with UC publications on management practices to protect surface water quality (Long et al. 2005; Meyer and Robinson 2007) and to use flowmeters (Hansen and Schwankl 1998; Schwankl et al. 2003) to quantify water and nutrient use for dairy forage crops. An online series of nine presentations on irrigation water management specific to dairy and liquid manure was created for dairy operators (Schwankl 2008). A compliance assistance binder was created (CDQAP-RB5 2007).

In the compliance assistance materials created for dairy operators and consultants were board-approved sampling protocols required by the GWDR, which also specified proper laboratory methods for analysis of the samples. The protocols were developed by UC, based on UC science and best professional understandings (Miller et al. 2018; Miller et al. 2019). The protocols help dairy producers obtain representative soil, solid and liquid manure, plant tissue and irrigation water samples for precisely managing nutrient applications and nutrient removals from land where manure was applied (Campbell Matthews and Frate 2008; Davy et al. 2009; Frate and Campbell Matthews 2008; Harter and Meyer 2007; Meyer and Mullinax 2008; Meyer 2008; Meyer et al. 2008; Meyer and Price 2011; Mueller and Putnam 2009; Pettygrove and Campbell Matthews 2008). A laboratory methods manual following US EPA methods was developed and went through stringent review by laboratory managers from other land grant universities familiar with these materials and the need for quality assurance (Holstege et al. 2010).

Fewer workshops were needed as dairy operators became more familiar with the GWDR, but the need continued for technical assistance on the detailed fieldby-field nutrient management plans required. These were to be prepared under the consultation of a certified crop advisor or technical services provider, and at the time, educational opportunities for these professionals did not address managing manure as a nutrient, so UC ANR again stepped up to fill the gap. UCCE specialists and advisors developed presentations on sample collection and handling, targeting nitrogen application to crop needs based on crop stage of production, and irrigation water management to reduce deep percolation of nitrate, as well as programs in backflow prevention related to potential cross contaminations on dairy operations.

The GWDR had a component related to mandatory groundwater monitoring. The Central Valley Dairy Representative Monitoring Program was developed to meet the groundwater monitoring requirements. Currently, many UC ANR specialists and advisors work with the Central Valley Dairy Representative Monitoring Program to provide technical advice on both the mandated groundwater monitoring program and the development of next-generation manure management practices more protective of groundwater. Ongoing development and dissemination of continuing education by CDQAP partners provides timely "news you can use" to dairy operators on manure management and water quality topics.

\section{North Coast, Bay Area dairy orders}

As the North Coast and San Francisco Bay Area regional boards approached the time to reissue conditional waivers for dairies, UC ANR and their partners in the CDQAP environmental stewardship program were engaged in the process, prior to the dairy orders being adopted in January 2012 and July 2015, respectively (NCRWQCB 2012; SFBRWQCB 2015). Once they were finalized, CDQAP organizations worked collaboratively to deliver workshops in Petaluma, Point Reyes, Ferndale and Rohnert Park to help dairy operators understand and meet compliance needs. These workshops, and also office hours, were held at least 

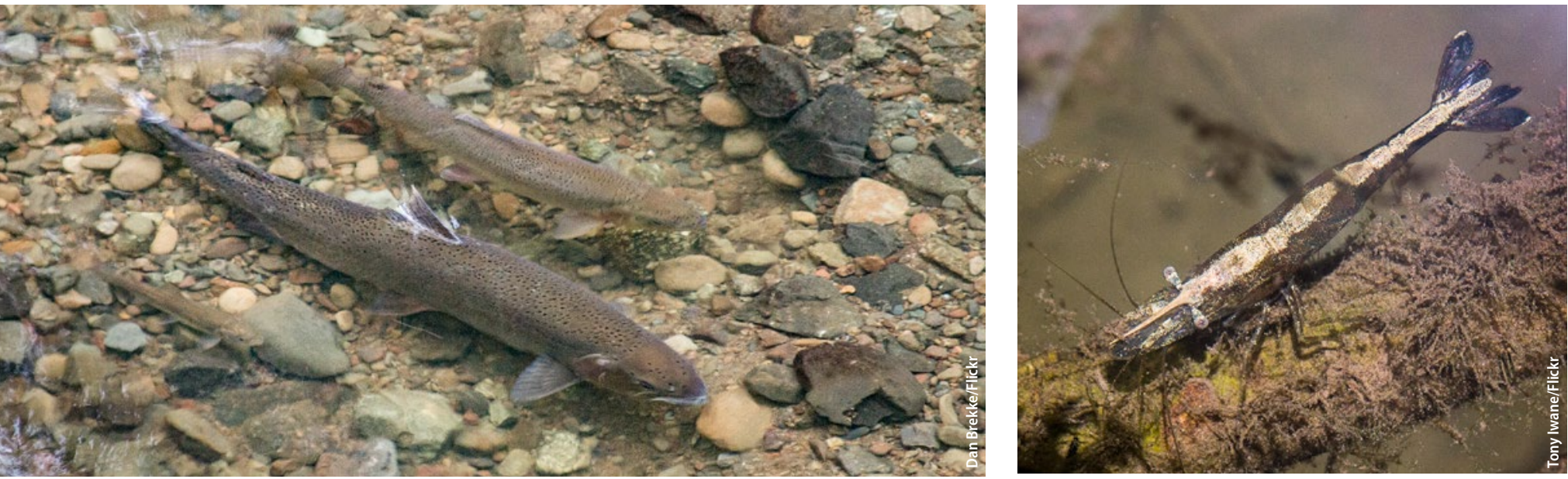

Regulation of un-ionized ammonia, which is toxic to fish and other aquatic life, is particularly important in watersheds like Stemple Creek that have a documented history of supporting (left) steelhead trout (Oncorhynchus mykiss) and (right) California freshwater shrimp (Syncaris pacifica).

\section{In Stemple Creek/Estero de San Antonio watershed, there has been a more than $95 \%$ reduction in un-ionized ammonia concentrations.}

twice annually during the first 2 years. Annual meetings are now held prior to the submission deadline of annual reports.

Unique needs in the North Coast and San Francisco Bay regional water quality control board jurisdictions included concerns about waterborne pathogens and toxic un-ionized ammonia from dairy enterprises entering aquatic habitats. In the case of pathogens, indicator bacteria are used as water quality constituents to protect water quality for shellfish harvesting and recreation. Un-ionized ammonia can be acutely toxic to cold water fishery species, including coho and steelhead

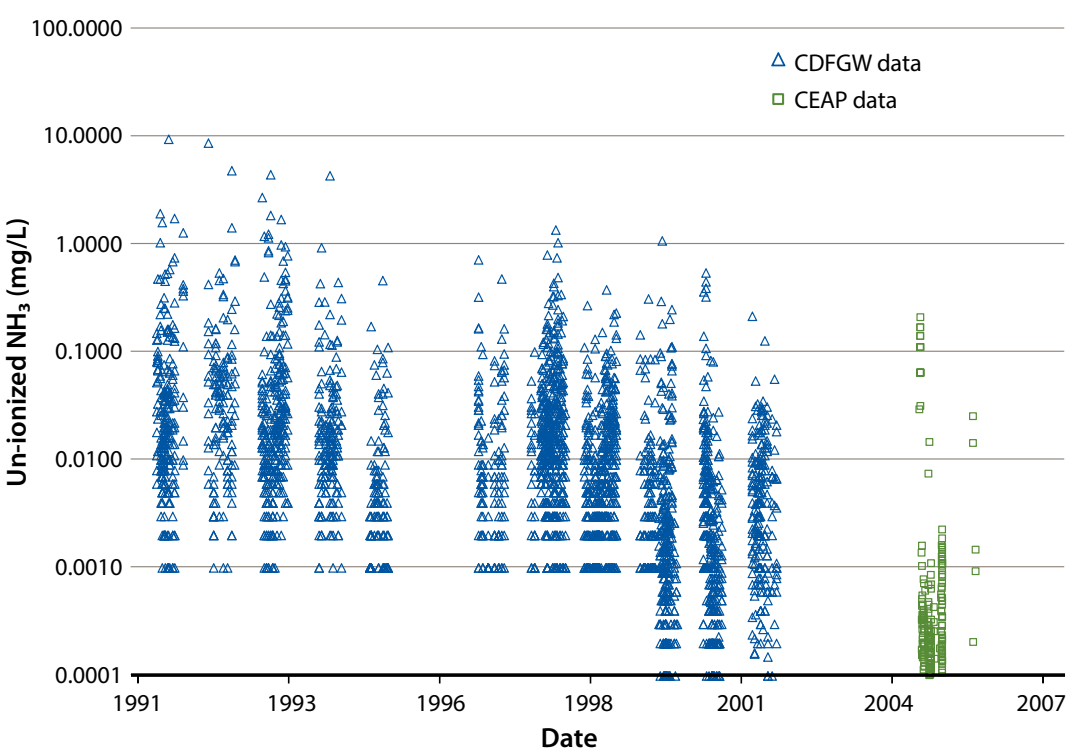

FIG. 1. Un-ionized ammonia concentrations in Stemple Creek watershed. Values are from unpublished data from the California Department of Fish Game (now California Department of Fish and Wildlife) sampling and analysis program from 1991 through 2001 and the Conservation Effects Assessment Program (CEAP) Study in 2005 and 2006 (Bingner et al. 2008). In 2000, a change in the analytical detection limit resulted in the reporting of lower limit values from that point on. trout, which are listed as endangered and threatened, respectively, on the North Coast.

Drawing upon work of UC ANR academics, systems understanding of bacteria fate and transport on area dairy farms was provided (Lewis et al. 2005) with specific management practice recommendations to reduce pathogen delivery from pastures that receive manure (Lewis et al. 2010) and high-use areas (Lewis et al. 2009). Additionally, recommendations for residual dry matter levels (Bartolome et al. 2002) served as guidelines for managing more extensively grazed areas of dairy farms.

The Animal Resource Management Committee, founded more than 30 years ago and responsible for monitoring and improving water quality in streams adjacent to dairy and animal operations in Sonoma and Marin counties, provided key organizational capacity. Staff from regulatory agencies and resource management agencies, dairy producers and technical service providers continue to meet monthly during the winter storm season. They share and discuss water quality data collected by surface water group monitoring programs and any regulatory agencies and work with the agricultural network to address identified problems through water quality planning and conservation practice implementation.

In Stemple Creek/Estero de San Antonio watershed, one of the watersheds covered by the committee, there has been a more than $95 \%$ reduction in un-ionized ammonia concentrations (fig. 1). Un-ionized ammonia is regulated on a concentration basis to prevent acute and chronic toxicity in surface water. Regulation is particularly important in watersheds like Stemple Creek that have a documented history of supporting steelhead trout (Oncorhynchus mykiss) and California freshwater shrimp (Syncaris pacifica).

Manure is a source of un-ionized ammonia and its direct delivery to streams and rivers. Using collected data to inform management, practices were 
implemented on watershed dairies that resulted in un-ionized ammonia concentrations decreasing from maximum values of nearly 10 milligrams per liter to less than 1 milligram per liter. The decrease was sustained through years of high precipitation, such as 1998, with 72.81 inches of rainfall, and through low rainfall years, like 2001, with just 23.54 inches (fig. 2).

Once the dairy orders were adopted, CDQAP again used a collaborative process for record keeping and reporting template development, review and approval. Compliance assistance binders were created and populated throughout a series of educational workshops (CDQAP-RB1 2012; CDQAP-RB2 2015); content included the work of UC ANR academics in pasture-based systems to address the specialized needs of pasture-based systems to be protective of water quality (Bartolome et al. 2002; Lewis et al. 2005). UC ANR worked to develop and deploy the workshops with dairy industry stakeholders (trade association and creamery representatives) and staff from other organizations: the two regional water boards, USDA NRCS and local resource conservation districts. Grants from the California Dairy Research Foundation and USDA Risk Management Agency offset costs for workshop materials and delivery.

\section{Impacts, lessons learned}

The record-keeping templates for dairy operators were an important outcome of these efforts. They helped operators to meet the regulatory requirements for documentation of facility evaluations before and after major storm events as well as other facility management needs. They gave regulatory agency staff confidence that producers were maintaining records about required practices. Workshops were also a key component of the education and outreach strategy, providing up-to-date technical information and answering detailed site-specific questions. Some of the more unique questions were forwarded to the appropriate regional boards' staff and served as the basis for question and

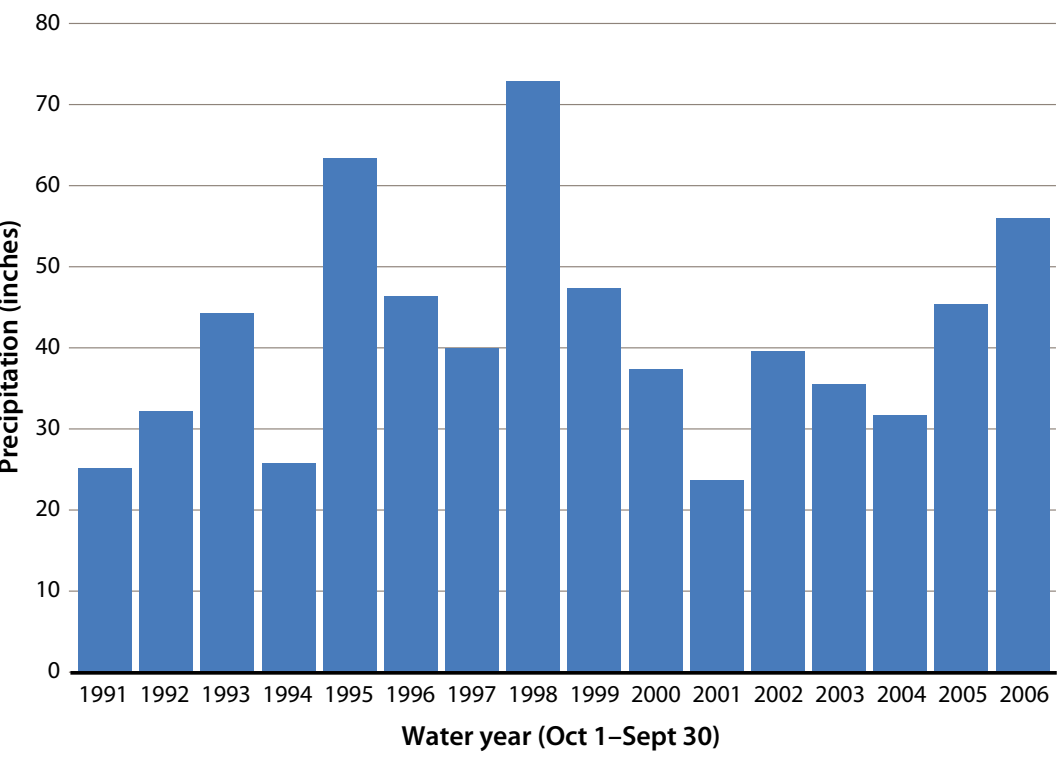

FIG. 2. Cumulative annual precipitation from 1991 through 2006 from Point Reyes Station, a coastal location approximately 10 miles south of Stemple Creek watershed, representative of the Point Reyes-Bodega Bay coastal region. Precipitation data are not from the studied Stemple Creek watershed because a continuous precipitation record is unavailable for that watershed.

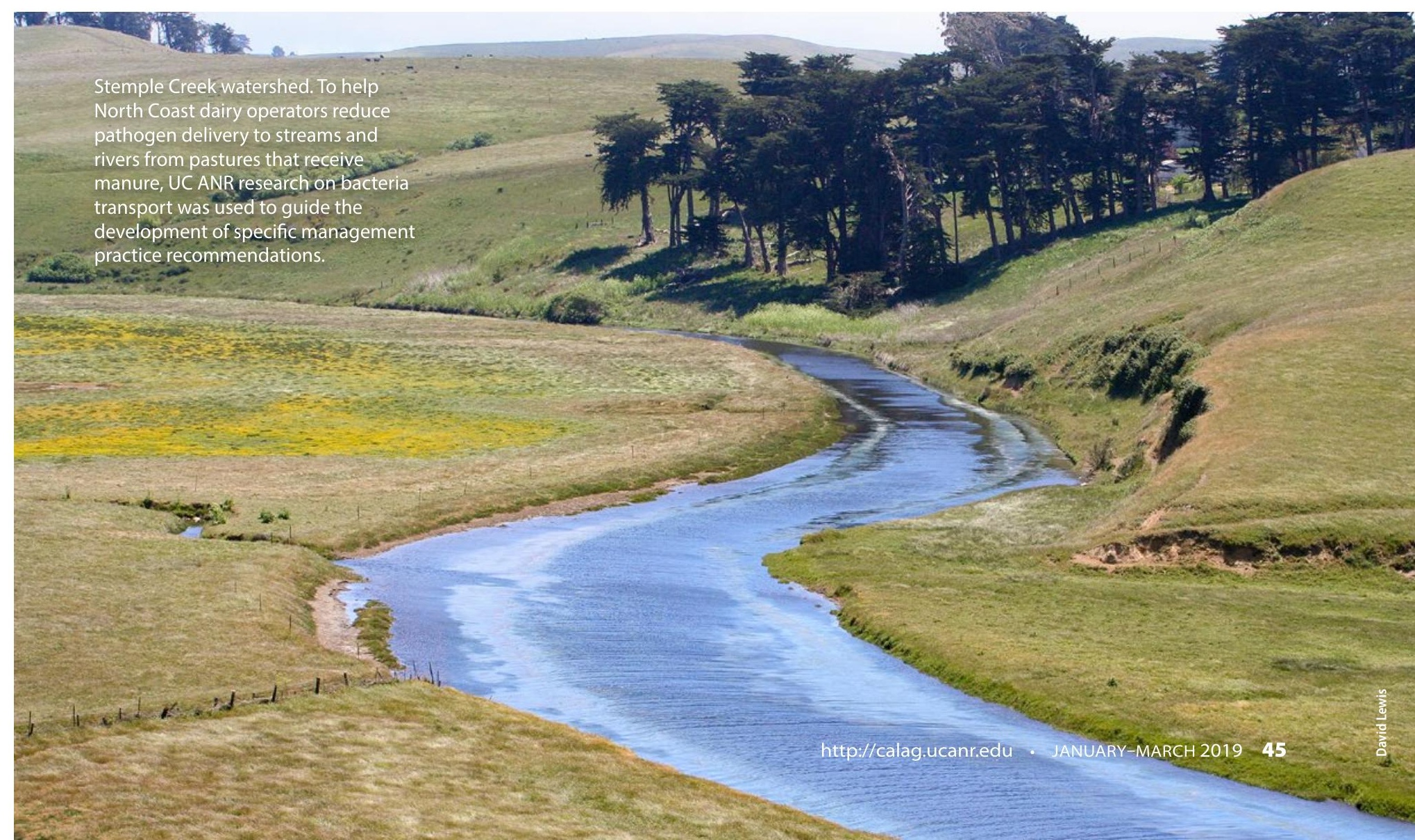




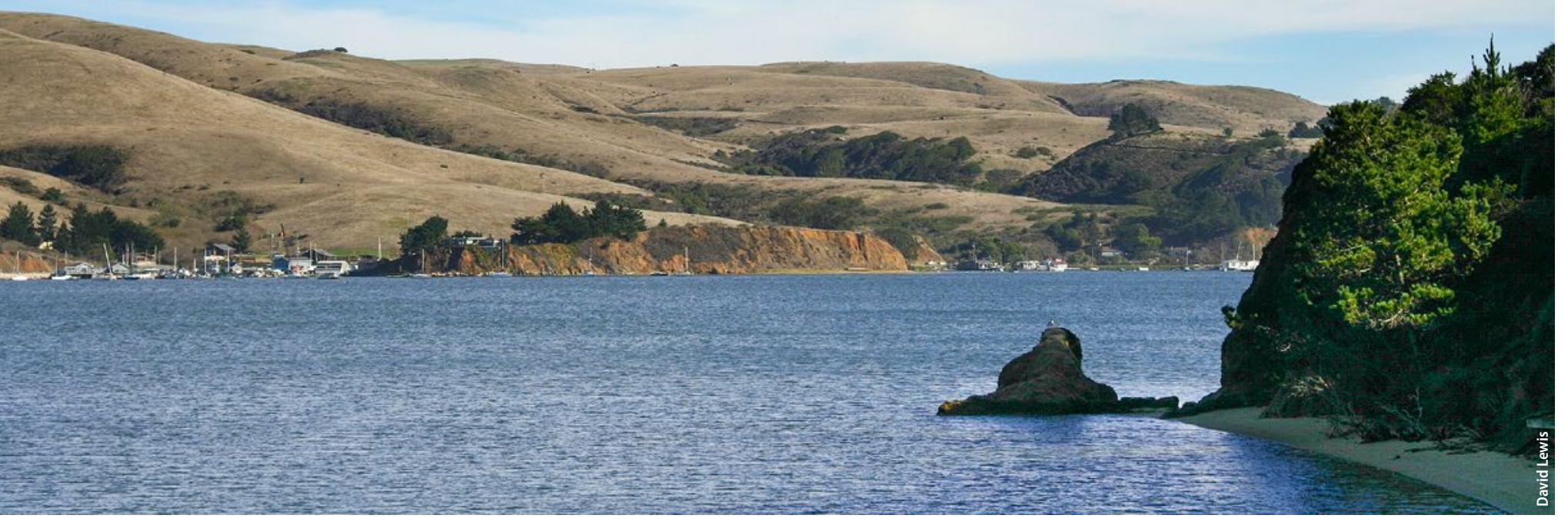

View across Tomales

Bay to the east shore, where grass-covered hills provide pasture for area dairies. The bay and its watershed support shellfish production and harvesting and are habitat for a diversity of wildlife. answer (Q\&A) documents on the board website. Surveys conducted at the end of workshops showed that dairy operators appreciated the opportunity to learn about the regulatory process.

Of greatest importance to the regional board staff was the compliance rate. More than $94 \%$ of Central Valley operators and $95 \%$ of North Coast and San Francisco Bay producers submitted required documents at each of the submission deadlines. This was far more than anticipated. Central Valley GWDR covered more than 1,400 dairy operations, and thereby was the largest number of permittees ever adopted by RB5 under one GWDR. The North Coast CWWDR applied to 126 facilities and the San Francisco Bay CWWDR applied to fewer than 50 facilities (including sheep and goat dairies). This high compliance rate allowed board staff to conduct compliance inspections instead of tracking down paperwork and educating dairy operators one-on-one about compliance needs.

In the Central Valley, facilities certified in the CDQAP environmental stewardship program are inspected less frequently (every 5 years rather than every 3 years) by board staff because they are also evaluated by a CDQAP contractor. Facilities certified under a state- or county-approved quality assurance program receive a 50\% WDR fee reduction (SWRCB 2016), a savings of up to $\$ 6,624$ per dairy annually.

Early in the process the workshops for consultants were improved by including a presentation on the emotional aspects of change, because consultants were reporting that some of their clients were exhibiting various stages of grief (denial, anger, bargaining, depression). Feedback was unanimous that the presentation provided consultants with insight to better understand why dairy producers were reacting as they were to the regulatory changes.

Some workshops experienced bumps and provided the workshop leaders opportunities to regroup. After attempting a classroom delivery to estimate manure storage pond capacity needs, they quickly identified that an alternative approach was needed. Office hours were set up at local sites near dairy operators so producers could work through the needed, site-specific calculations with one-on-one assistance.

Delivery of educational workshops and scientific information to dairy farmers and their consultants was important for a greater understanding of regulatory requirements. UC ANR has worked with regulatory boards and hundreds of dairy farmers and dozens of consultants while navigating a multitude of production systems (from 20 to 10,000 cows, organic and conventional, pasture-based and confinement facilities) and regulatory environments (regional board requirements, county building requirements, county animal permitting requirements and air management districts regulations). As additional regulations take shape, UC ANR will continue to deliver scientific information and work with its partners to influence the state's water quality policy.

Improved dairy manure management practices to maintain or improve surface water or groundwater quality are achieved through incremental steps. UC ANR involvement at the local and state level has provided invaluable research into subjects critical to specific water quality needs. Analysis of management practices to improve nitrogen management, minimize nonpoint source impacts to surface waters, and evaluate manure treatment technologies takes time and much repetition to represent different geographic areas. On-farm and regional research is ongoing to better inform policymakers developing water quality policy. Change in management practices and ultimate improvements to surface water and groundwater quality comes when individual dairy operators modify practices. Through collaborative efforts, UCANR and CDQAP have been leaders in the development and delivery of award-winning outreach programs to improve environmental management and sustainability at dairies with owner/operator participation. CA 
D.M. Meyer is UC Cooperative Extension (UCCE) Livestock Waste Management Specialist, Department of Animal Science, UC Davis; B.M. Karle is UCCE Dairy Advisor, Glenn, Tehama and Butte counties; J.M. Heguy is UCCE Dairy Advisor, San Joaquin, Stanislaus and Merced counties; D.J. Lewis is UCCE Watershed Management Advisor, Marin and Napa counties; J.W. Stackhouse is UCCE Livestock and Natural Resource Advisor, Humboldt and Del Norte counties; and D.D. Mullinax is Assistant Manager, CDQAP, and Interim Manager, California Dairy Research Foundation.

The success of this program would not have been possible without the support of the following CDQAP partner agencies: California Dairy Research Foundation, Western United Dairymen, Milk Producers' Council, California Farm Bureau, California Dairy
Campaign, Sustainable Conservation, the three regional water quality control boards and San Joaquin Air Pollution Control District. Specifically, industry contributors Paul Martin, Paul Sousa and Melissa Lema of Western United Dairymen; Kevin Abernathy of Milk Producers' Council; and Frances Tjarnstrom of Humboldt County Resource Conservation District dedicated innumerable hours of outreach and guidance throughout the process.

UC ANR collaborators Shannon Mueller, Marsha CampbellMatthews, G. Stuart Pettygrove, Thomas Harter, Carol Frate, Larry Schwankl, Allan Fulton, Doug Munier, Josh Davy, Bill Krueger, Carol Collar, Gerald Higginbotham and Alejandro Castillo were integral in providing technical expertise during the educational process.

\section{References}

Bartolome JW, Frost WE, MCDougald NK, Connor M. 2002 California Guidelines for Residual Dry Matter (RDM) Manage ment on Coastal and Foothill Annual Rangelands. UC ANR Pub 8092. Oakland, CA. p 1-7. Bingner R, Langendoen $\mathrm{E}$, Lewis D, et al. 2007. Evaluation of conservation practices in the NRCS CEAP Special Emphasis Stemple Creek Watershed. In: Proc Ann Soil and Water Conserv Soc, Jul. 21, 2007. Tampa, FL.

California Code of Regulations Title 27, Division 2, Subdivision 1, Chapter 7, Subchapter 2. Article 1. SWRCB-Confined Animal Facilities. https://govt.westlaw. $\mathrm{com} /$ calregs/Browse/Home/

California/CaliforniaCodeofRegu lations?guid=121 AB9A20D4501 1DEA95CA4428EC25FA0\&origin ationContext=documenttoc\&tr ansitionType=Default\&contextD ata $=$ (sc. Default)

California State Legislature. 2003. SB 923, Chapter 801: An Act to Amend Section 13269 of the Water Code, Relating to Water. www.leginfo.ca.gov/ pub/03-04/statute/ch 08010850/ch_801_st_2003_sb_923

Campbell Matthews M, Frate C. 2008. Forage Crops - Corn and Winter Forage Sampling Protocol. CDQAP- WDR General Order Reference Binder.

CDQAP-RB1. 2012. California Dairy Quality Assurance Program North Coast RB1 Water Quality Reference Binder. http://cdrforg/home/ checkoff-investments/cdqap/ about-the-environmental-stewardship-program/north-coastreference-binder/

CDQAP-RB2. 2015. California Dairy Quality Assurance Program San Francisco Bay RB2 Water Quality Reference Binder. http://cdrforg/home/ checkoff-investments/cdqap/ about-the-environmentalstewardship-program/northcoast-rb2-reference-binder/
CDQAP-RB5. 2007. California Dairy Quality Assurance Program Central Valley RB5 Water Quality Reference Binder. http://cdrforg/home/ checkoff-investments/cdqap/ about-the-environmentalstewardship-program/ wdr-general-order-referencebinder-materials/

Chang A, Harter T, Letey J, et al. 2006. Groundwater Quality Protection: Managing Dairy Manure in the Central Valley of California. UC ANR Pub 9004. Oakland, CA. $178 \mathrm{p}$.

[CVRWOCB] Central Valley Regional Water Quality Control Board. 2007. California Regiona Water Quality Control Board Central Valley Region Order R5-2007-0035: Waste Discharge Requirements General Order for Existing Milk Cow Dairies. www.waterboards.ca.gov/centralvalley/board_decisions/adopted_orders/general_orders/ r5-2007-0035.pdf

CVRWOCB. 2013. California Regional Water Quality Control Board Central Valley Region Order R5-2013-0122: Reissued Waste Discharge Requirements General Order for Existing Milk Cow Dairies. www.waterboards. ca.gov/centralvalley/board_decisions/adopted_orders/general_orders/r5-2013-0122.pdf

Davy J, Doran M, Karle B, Meyer D. 2009. Sampling Protocol for Irrigated Pastures CDQAP-WDR General Order Reference Binder. Frate C, Campbell Matthews M. 2008. Irrigation (Fresh) Wate Sampling Protocol. CDQAPWDR General Order Reference Binder.

Hansen B, SchwankI L. 1998. Water turbulence disrupts accuracy of some flow meters. Calif Agr 52(1):25-30
Harter T, Davis H, Mathews MC Meyer RD. 2001. Monitoring shallow groundwater nitrogen loading from dairy facilities with irrigated forage crops. In: Proc ASAE Ann Int Mtg, July 30-Aug. 1, 2001. Sacramento, CA. Paper 01-2103.

Harter T, Davis H, Mathews MC, Meyer RD. 2002. Shallow groundwater quality on dairy farms with irrigated forage crops. J Contam Hydrol 55(34):287-315.

Harter T, Mathews MC, Meyer RD. 2001. Effects of dairy manure nutrient management on shallow groundwater nitrate: A case study. In: Proc ASAE Ann Int Mtg, July 30-Aug. 1, 2001. Sacramento, CA. Paper 01-2192. Harter T, Meyer D. 2007. Sampling Supply Wells and Subsurface (Tile) Drainage Systems. CDQAP-WDR General Order Reference Binder. http://cdrf org/wp-content/uploads/2012 106/5_1SamplingWells-revisedMarch-2011.pdf

Holstege D, Price P, Miller RO, Meyer D. 2010. California Analytical Methods Manual for Dairy General Order Compliance — Nutrient Management Plan Constituents. UC Davis Analytical Laboratory. https:// anlab.ucdavis.edu/media/pdf/ uc_analytical_methods.pd

Lewis DJ, Atwill ER, Lennox MS, et al. 2005. Linking on-farm dairy management practices to storm-flow fecal coliform loading for California coastal watersheds. Environ Monit Assess 107(1):407-25.

Lewis DJ, Atwill ER, Lennox MS et al. 2009. Reducing microbial contamination in storm runoff from high use areas on California coastal dairies. Water Sci Technol 60(7):1731-4.

Lewis DJ, Atwill ER, Lennox MS, et al. 2010. Reducing microbial contamination in storm runoff from California coastal dairy pastures. J Environ Qual 39:1782-9.
Long R, Gan J, Nett M. 2005. Pesticide Choice: Best Management Practice (BMP) for Protecting Surface Water Quality in Agriculture. UC ANR Pub 8161 Oakland, CA. 7 p.

Mathews MC, Swenson E, Harter T. Meyer D. 2001. Matching dairy lagoon nutrient application to crop nitrogen uptake using a flow meter and control valve. In: Proc ASAE Ann Int Mtg July 30-Aug. 1, 2001. Sacramento, CA. Paper 01-2105.

Meyer D. 2008. Process Wastewater (Liquid Manure) Sampling Protocol. CDQAP-WDR General Order Reference Binder.

Meyer D, Mullinax D. 2008. Solid Manure Sampling Protocol. CDQAP-WDR General Orde Reference Binder.

Meyer D, Price P. 2011. Supply Well and Tile Drain Sample Field Analysis for Ammonium Nitrogen. CDQAP-WDR General Order Reference Binder.

Meyer D, Price P, Karle B. 2008.

Solid Manure Moisture Content

Determination - Microwave

Method for Exported Solid

Manures. CDQAP-WDR General

Order Reference Binder.

Meyer D, Robinson P. 2007. Use of Feed Inventory Records to Reduce Nutrient Loading at Dairy Operations: Producers Options. UC ANR Pub 8277.

Oakland, CA. 6 p.

Miller CMF, Fadel JG, Heguy

JM, et al. 2018. Optimizing accuracy of protocols for measuring dry matter and nutrient yield of forage crops. Sci Total Environ 624:180-8. https://doi.org/10.1016/j.scitotenv.2017.11.203

Miller CMF, Heguy JM, Karle BM et al. 2019. Optimizing accuracy of protocols to measure nutrient content of solid manure. Waste Manage. In press.

Mueller S, Putnam D 2009. Sampling Alfalfa Hay. CDQAP-WDR General Order Reference Binder.

[NCRWQCB] North Coast Regional Water Quality Contro Board. 2012. California Regional Water Quality Control Board North Coast Region Order R12012-0003: Conditional Waiver of Waste Discharge Requirements for Existing Cow Dairies in the North Coast Region. www.waterboards.ca.gov/ northcoast/water_issues/ programs/dairies/pdf/120127/ waiver/120127_12_0003 Waiver_Dairy.pdf

Pettygrove GS, Campbell Matthews M. 2008. Soil Sampling Protocol. CDQAP-WDR General Order Reference Binder.

Ristow PL, Pettygrove GS, Meyer DM, et al. 2006. California Dairies - Protecting the Environment. Sustainable Agriculture Research \& Education Program. UC ANR Pub 21630. Oakland, CA.

Schwankl LJ. 2008. Dairy Irrigation Water Management Series, UC ANR Narrated PowerPoint Presentations. http://ucanr.edu/ sites/irrmgm/narrated_powerpoint_presentations/ (accessed Jul. 20, 2017).

Schwankl L, Eagle A, Frate C Nydam B. 2003. Flow meters tested on dairy lagoon water. Calif Agr 57(3):93-6.

[SFBRWQCB] San Francisco Bay Region Water Quality Control Board. 2015. California Regional Water Quality Control Board San 